\title{
De servidores públicos marajás a profissionais eficientes: uma genealogia das práticas de poder e resistência a partir de um grupo de discussão
}

From maharaja public servants to efficient professionals: a genealogy of the practices of power and resistance from an online discussion group

De servidores públicos marajás a profesionales eficientes: una genealogía de las prácticas de poder y resistencia a partir de un grupo de discusión en línea

$\begin{aligned} & \text { Paula Fernandes Furbino Bretas } \text { } \\ & \text { Mestrado em Administração (Concentração em Estudos Organizacionais e Sociedade) pela Universidade Federal de Minas Gerais }\end{aligned}$ http://lattes.cnpq.br/4637687387433353 https://orcid.org/0000-0002-7120-0574 paulaffb@gmail.com

RESUMO: Objetivou-se neste artigo compreender como um grupo de discussão online foi produzido e transformado em práticas de poder e resistência em uma organização pública. Buscou-se desenvolver reflexões sobre as relações de poder e seus efeitos a partir do poder disciplinar, observando os regimes de verdade do Neoliberalismo e da Nova Gestão Pública como condições de emergência do grupo. Metodologicamente, seguiu-se as diretrizes da genealogia para fazer um estudo de caso qualitativo em uma perspectiva histórica. Alguns achados de pesquisa incluem os processos de subjetivação de trabalhadores despolitizados e a possibilidade de resistências multiformes que se transformam constantemente no jogo de poder.

Palavras-chave: Poder disciplinar. Resistência. Neoliberalismo. Nova Gestão Pública. Perspectiva Histórica.

\begin{abstract}
In this article, the purpose was to understand how an online discussion group has been produced and transformed into practices of power and resistance in a public organization. It was sought to develop reflections on power relations and their effects on the disciplinary power, observing the truth regimes of Neoliberalism and the New Public Management as the emerging conditions of the group. Methodologically it followed the genealogy guidelines to make a qualitative case study in a historical perspective. Some research findings include the process of subjectification of depoliticized workers and the possibility of multiform resistance that constantly transform the power game.

Keywords: Disciplinary Power. Resistance. Neoliberalism. New Public Management. Genealogy.
\end{abstract}

RESUMEN: Se ha tratado en este artículo comprender cómo un grupo de discusión en línea fue producido y transformado en prácticas de poder y resistencia en una organización pública. Se buscó el desarrollo de reflexiones sobre las relaciones de poder y sus efectos a partir de poder disciplinario, observando los regímenes de verdad del Neoliberalismo y de la Nueva Gestión Pública como condiciones de emergencia de grupo. Metodológicamente, se siguieron las directrices de la genealogía para hacer un estudio de caso cualitativo en una perspectiva histórica. Algunos resultados de investigación incluyen los procesos de subjetivación de trabajadores despolitizados y la posibilidad de resistencias multiformes que se transforman constantemente en el juego de poder.

Palabras clave: Poder disciplinario. Resistencia Neoliberalismo. Nueva Gestión Pública. Genealogía.

\section{Introdução}

Objetivou-se neste artigo compreender como um grupo de discussão online foi produzido e transformado em práticas de poder e resistência em uma organização pública. Não são raros os estudos sobre poder (Mintzberg, 1992, 1995; Lana, Paines, Bonaldo, \& Muller 2016; Santos \& Claro, 2014) em uma concepção negativa na Administração, isto é, o poder que diz "não", proíbe e controla. Influenciados pelos estudos weberianos sobre a burocracia, cuja análise é na estrutura, esses estudos citados sobre poder tentam localizar o poder na organização, na autoridade, na hierarquia, no Estado ou algum outro centro de poder (Clegg, 1994;Pereira, 2014), conferindo-Ihe, assim, uma característica de atributo que se possui (ex. o poder do gerente).

Os estudos baseados em Foucault nos Estudos Organizacionais são de diversas naturezas, como estudos teóricos (Ferreirinha \& Raitz, 2010; Lemos, Rodriguez \& Monteiro, 2011), teórico-empíricos (Alcadipani \& Almeida, 2000; Capelle \& Brito, 2003; Silva \& Alcadipani, 2004; Xavier \& Godoi, 2010) ou epistemológicos (Souza, Machado \& Bianco, 2008; Cavalcanti \& Alcadipani, 2011; Pereira, Oliveira \& Carrieri, 2012; Costa, Guerra \& Souza-Leão, 2013). Entretanto, acredita-se ser necessário aprofundá-los, tentando sair da instrumentalização na utilização do poder disciplinar (Souza, Junquilho, Machado, \& Bianco , 2006), a partir da construção de uma genealogia com influências da nova história (Souza \& Costa, 2013) e da articulação desta com o cotidiano (Barros \& Carrieri, 2015).

Não se busca aqui uma fonte para o poder (p. ex., o gerente como seu possuidor), pois se segue a premissa de Foucault (2014), de que poder não é algo que se tem e nem se localiza no centro. É a busca pelo "como", e não pelo "onde" ou "quem". Acredita-se que não centralizar o poder significa ampliar os horizontes da análise para os contextos sociais, de forma a vislumbrar relações de podersaber que sustentam regimes de verdade de cada época. Isto é perceber como alguns conhecimentos são legitimados como "verdadeiros" em detrimento de outros, como existem condições externas que ocasionam essa legitimação, como o poder é constituído e exercido nesse processo de legitimação de saberes, bem como observar "quem profere os discursos que o legitimam, e também a formação de identidades, individuais e institucionais, que decorrem deste processo" (Abumanssur, 2016).

Nessa análise do macro ao micro, entende-se que o poder é exercido, se dá nas relações sociais, e é também disperso, capilar, de maneira que chega aos indivíduos atingindo seus corpos, 
discursos, gestos, atitudes, aprendizagem, enfim, sua vida cotidiana (Foucault, 2014). Essa abordagem positiva para o poder se difere de outras abordagens para a análise do objeto de estudo do presente artigo, pois desloca o foco da análise da estrutura e dos indivíduos para análise das relações sociais e processos de subjetivação.

$\mathrm{Na}$ dispersão das relações de poder, coaduno com Foucault (2014): onde há poder, há resistências. Nessa concepção, buscase sair da noção de que a resistência é um contra-poder (Misoczky, Flores \& Böhm, 2008; Misoczky, Moraes \& Flores, 2009) para uma abordagem foucaultiana, na qual a resistência "não é anterior ao poder que ela enfrenta. Ela é coextensiva a ele e absolutamente contemporânea", não sendo uma imagem invertida do poder, mas algo como o poder inventivo, produtivo e móvel (Foucault, 2014, p.360). Essa noção permite a análise crítica da instabilidade dos processos sociais, o que escapa às perspectivas funcionalistas $e$ perspectivas baseadas nas teorias crítica e marxista.

Diante disso, analisa-se um grupo de discussão online criado a partir do Yahoo!Grupos por trabalhadores de uma organização pública, denominado aqui como LEGOi. Os interessados em fazer parte do GRUPOii, para receber, trocar e responder e-mails dos participantes, se inscrevem com seu e-mail institucional. A criação do grupo teve ampla repercussão e, em vários momentos de sua história, foi considerado como resistência, ora à administração, ora aos políticos envolvidos na organização, ora a concepções político partidárias vigentes em determinada época. Observa-se uma espécie de tabu em um contexto de interdições, pois nos rumores e advertências sobre o GRUPO, há comparações com "uma caixa de vespeiro". Tal contexto é explicado pela ideia de interdição foucaultiana, segundo a qual "sabe-se bem que não se tem o direito de dizer tudo, que não se pode falar de tudo em qualquer circunstância, que qualquer um, enfim, não pode falar de qualquer coisa" (Foucault, 2013a: 9)

Percebe-se o GRUPO, assim, como um paradoxo: ao mesmo tempo em que era uma possibilidade de dar visibilidade aos pontos de vista e demandas dos trabalhadores, era de certa forma controlado pela organização e sujeito a sanções e punições. Ao reconstruir uma versão da história do GRUPO, a partir da memória dos participantes, observa-se a sua plasticidade e fragmentação, de um grupo rebelde a conformado e de um grupo atuante como resistência a um grupo passivo e silenciado. Mas isso não limita e restringe as possibilidades de resistências dos trabalhadores. Demonstra apenas as múltiplas formas que elas adquirem na medida em que os processos de normalização atravessam os corpos. Processos esses que conduzem as condutas, os gestos e os discursos dos sujeitos envolvidos em prol de regimes de verdade que legitimam os saberes que coadunam ideais do Neoliberalismo e da Nova Gestão Pública.

Além desta introdução, o artigo possui mais quatro seções. $\mathrm{Na}$ primeira, foram discutidos as relações de poder e resistência e o desenvolvimento do poder disciplinar; na segunda, são apresentados os aspectos metodológicos; na terceira, há uma contextualização, a partir do Neoliberalismo e da Nova Gestão Pública, e a construção de uma narrativa histórica das resistências relativas ao GRUPO; por fim, na quarta e última seção, são tecidas as considerações finais.

\section{Fundamentos teóricos}

\section{As relações de poder e resistência}

Para Foucault (2014), o poder é algo que se exerce, estando no domínio da ação. Contra a abordagem negativa do poder, Díaz (2012) afirma que se o poder fosse somente repressivo não seria obedecido. Logo, a concepção negativa do poder está ligada à abordagem jurídico-discursiva de uma lei que diz não (Foucault, 2013b). Entretanto, para Foucault (2014), o poder não deve ser algo procurado no centro, nas posições hierárquicas, pois ele é capilar. Dessa forma, ele se manifesta em todo o corpo social, na vida cotidiana do indivíduo, na conduta de gestos, atitudes, trabalho, rotinas e discursos.

Portanto, o poder não é nem uma propriedade nem um direito que consagra o possuidor como pregava a teoria jurídica clássica. E também não é da ordem da repressão (Foucault, 2014); do poder que serve à manutenção de relações de produção para a dominação de uma classe sobre a outra, como desenvolveu o marxismo. Ambas as abordagens, teoria jurídica e marxismo, secundarizam o poder em relação à economia (Foucault, 2014). Entretanto, mesmo depois da revolução, as relações de poder cotidianas permaneceram as mesmas na União Soviética, o que fez Foucault (2010) acreditar que só mudaremos a sociedade se mudarmos essas relações, consideradas até então como marginais, mas que ocupam uma posição central no domínio político, já que o poder não estaria ligado apenas ao Estado, mas sim, operando em lugares múltiplos, abrangendo problemas relacionados à psiquiatria, à sexualidade, à família, dentre outros.

Sobre relações de poder e resistência, Foucault procura se aproximar da ideia de estratégia sem estrategistas, no intuito de se afastar de abordagens psicologizantes. Ao invés de intencionalidade explícita ou motivações psicológicas como fontes, Foucault observa o movimento das relações de força, preocupandose mais com disposição, manobras, táticas, técnicas e funcionamento. Desse primeiro argumento, conclui-se que não há dominados e dominadores; nem um sujeito movendo a história, seja ele individual ou coletivo, mas um jogo de forças (Dreyfus \& Rabinow, 2013). Isso porque, nessa concepção, "os sujeitos não preexistem para, em seguida, entrar em combate ou em harmonia. Na genealogia, os sujeitos emergem em um campo de batalha, e é somente aí que desempenham seus papéis" (Dreyfus \& Rabinow, 2013, p.146).

Foucault (2010) ressalta, ainda, que essas relações não são regidas por uma regra universal, mas sim possuem suas próprias tecnologias e métodos. $E$ também que não são relações extremas como "Faça isto ou te mato", pois existe uma noção de enfrentamento e de reversibilidade na rede de forças. Essas resistências possuem, portanto, um papel complexo na relação de poder, pois aquela força que domina, para continuar dominando perante às resistências, precisa tentar se manter com mais força $e$ mais astúcia. Dessa forma, é possível perceber mais um campo de batalha, uma luta perpétua, multiforme e em movimento, do que 
algo estanque (Foucault, 2010). O poder pode ser, assim, visto como um diagrama (Díaz, 2012) que "vai da rebelião à dominação, da dominação à rebelião” (Foucault, 2010, p.232).

$\mathrm{Na}$ defesa de que o poder produz o próprio homem (Souza et al., 2006), atravessado por forças de naturezas diversas, conseguiremos entender quem é o trabalhador que participa do GRUPO, na década de 1990, identificando o jogo bélico entre essas forças e as relações de poder-saber engendradas, com foco no poder disciplinar para compreensão dos processos de subjetivação vivenciados por esses sujeitos.

\section{O desenvolvimento do poder disciplinar}

Em seus estudos sobre poder, Foucault postula sobre as disciplinas, que se referem ao governo dos corpos dos indivíduos, e sobre a biopolítica, que se refere ao governo das populações. Neste artigo, o foco recairá sobre as disciplinas, que é uma categoria de poder específica, mesmo sabendo das diferenças de contextos históricos entre aquele que o autor estudou as prisões e o contexto do presente estudo. Contudo, acredita-se que a noção de disciplina como

uma rede de relações entre elementos heterogêneos (instituições, construções, regulamentos, discursos, leis, enunciados científicos, disposições administrativas) que surge com vistas a uma determinada finalidade estratégica (nesse caso, a produção de indivíduos politicamente dóceis e economicamente rentáveis) e cujo funcionamento e cujos objetivos podem modificar-se para adaptarse a novas exigências (Castro, 2014, p. 92)

O que coaduna com a visão presente neste artigo de que é possível estudar as relações de poder em vários níveis, sem manter o foco, nem na estrutura, nem no indivíduo, mas nos processos diversos que movimentam o jogo de forças.

O principal objetivo do poder disciplinar é tornar o corpo dócil e produtivo; é analisá-lo para manipulá-lo, treiná-lo. Assim, a disciplina atua em um jogo de forças perante o corpo, no qual se aumenta as forças em termos econômicos de utilidade e diminui as forças em termos políticos de obediência (Foucault, 2013b). O exercício da disciplina exige um olhar vigilante, mas que não é visto. Percebemos como, atualmente, as tecnologias de informação cumprem essa função de vigilância nem sempre visível, seja na prática da biopolítica (Stassun \& Prado Filho, 2012), ou no controle nas organizações (Bessi, Zimmer \& Grisci, 2007).

Dreyfus e Rabinow (2013) indicam que foi nas escolas e nas forças armadas que as disciplinas desenvolveram técnicas e táticas para tratar o corpo como objetos a serem moldados. Segundo os autores, era necessário um padrão que unificasse operações e solidificasse punições para fazer funcionar esse sistema disciplinar. Tal padrão seria a sanção normalizadora, que consiste em micropenalidades, devidas em função de desvios cotidianos, o que transformou o dissidente em objeto da atenção disciplinar.

Para Foucault (2013b), essa infrapenalidade existe no espaço, não ocupado pelas leis, e atuam qualificando e reprimindo comportamentos que escapam aos grandes sistemas de castigo, como desvios em relação ao tempo (atrasos, ausências, interrupções de tarefas), à atividade (desatenção, negligência, falta de zelo), à maneira de ser (grosseria, desobediência), aos discursos (tagarelice, insolência), ao corpo (atitudes "incorretas", gestos fora da conformidade) e à sexualidade (imodéstia, indecência). Essas punições podem abranger tanto castigos físicos leves, quanto privações ligeiras e pequenas humilhações.

Ao possibilitar que diferentes elementos de um aparelho disciplinar tenham função punitiva e, ao dividir a conduta em frações penalizáveis, cria-se uma universalidade que prende o indivíduo em um continuum punível-punidora. Diferente da separação jurídica de permitido-proibido, os comportamentos são situados e graduados entre os polos do bem e do mal (Foucault, 2013b), estabelecendose uma "hierarquia objetiva através da qual a distribuição dos indivíduos era justificada, legitimada e tornada mais eficaz" (Dreyfus \& Rabinow, 2013, p.208). Portanto, ao existir uma conformidade e uma regra, o que Ihe extrapola é desvio passível de penalidade baseada em uma quantificação, em uma economia das penas (Foucault, 2013b).

Foucault (2010, p.311) acredita que "os controles psicológicos são sempre mais eficazes que os controles físicos". Logo, na disciplina, a punição atua no sistema gratificação-sanção, evitando o uso de castigos e aumentado as recompensas, sendo estas mais frequentes que as penas. Dessa forma, há incitação por recompensas e receio dos castigos e, dessa microeconomia, os aparelhos disciplinares conseguem hierarquizar os indivíduos entre bons e maus (Foucault, 2013b).

Conforme o autor, ao hierarquizar grupos de indivíduos, além da distribuição segundo aptidões e comportamentos, existe um exercício de pressão constante para que os indivíduos dos grupos inferiores (maus, vergonhosos) se submetam ao mesmo modelo e ascendam aos grupos superiores (bons) e, assim, todos se pareçam. Portanto, a arte de punir precisa fazer funcionar a coação de uma conformidade, traçando o limite que definirá a fronteira externa do anormal, sem tomar por referência um conjunto de leis e sim um conjunto de fenômenos observáveis. Por isso, ela "compara, diferencia, hierarquiza, homogeniza, exclui. Em uma palavra, ela normaliza” (Foucault, 2013b, p.176). Tal normalização é um dos principais efeitos dos processos de subjetivação que se busca compreender neste artigo.

\section{Procedimentos metodológicos}

Foucault (2013a) ressalta que cada momento histórico possui condicionantes que o permitem assim ser. Dessa forma, mais do que procurar "a verdade", procura-se as vontades de verdade vigentes em cada período e as suas transformações sóciodiscursivas, de forma a restituir o caráter de acontecimentos do discurso, e suspender a soberania do significante (Foucault, 2013a). Assim, antes de retornar às relações de poder que atravessam os sujeitos e conduzem discursos, gestos e atitudes nos processos de subjetivação, busca-se entender como os conhecimentos nessa história se tornaram legitimados para entender sua relação de poder-saber manifesta no cotidiano.

Dreyfus e Rabinow (2013) descrevem a tarefa do genealogista como destruidor de verdades imutáveis, da primazia da origem, das doutrinas de desenvolvimento e progresso em um ambiente permeado de sujeição, dominação e luta. Sobre tal ambiente, Díaz (2012) corrobora os autores afirmando que o enfrentamento é, 
propriamente, o lugar, e exemplifica algumas emergências em meio a esses enfrentamentos, como o surgimento da diferenciação de valores na dominação de homens sobre homens ou da ideia de liberdade na dominação de uma classe sobre outra. Dessa forma, a genealogia não tenta nada menos do que fazer uma história de algumas interpretações que surgem de lutas, partindo da premissa de que o devir da humanidade é um conjunto de interpretações (Foucault, 2010), sem origem, sem essência, sem ligação direta entre natureza e linguagem.

Dessa forma, se pensarmos o discurso como "elemento que confere materialidade e plasticidade às relações de poder" (Pereira, 2014, p. 16), podemos analisá-lo enquanto prática social que constitui e é constituído pelos efeitos de verdade. Na busca desse empreendimento genealógico, foi feita uma breve análise do Neoliberalismo e da Nova Gestão Pública, como os discursos legitimados nessa relação poder-saber contemporâneos ao surgimento e ao desenvolvimento do GRUPO na LEGO.

Assim como Vizeu (2010), Costa, Barros e Martins (2010), Souza e Costa (2013) e Barros e Carrieri (2015), acredita-se que a pesquisa organizacional precisa se voltar para as especificidades locais na tentativa de compreender a singularidade das práticas organizacionais em um contexto sociocultural próprio. Souza e Costa (2013) argumentam que a genealogia proposta por Foucault (2010; 2013a; 2013b; 2014) possui aproximações possíveis com a nova história sendo inclusive influenciada e influenciadora desse movimento, dentre elas,

[...] (a) o combate comum a uma visão linear, contínua e progressiva da história; (b) o abandono da busca dos grandes feitos dos grandes homens (grandes inventores, grandes descobridores) e o interesse por uma história vista de baixo, ou seja, pelas opiniões e experiências de pessoas comuns como agentes da história (trabalhadores, presos, prostitutas, homossexuais, mulheres etc.); (c) a concordância em relação à transformação (e ampliação) da noção de documento, não mais considerado um dado, mas, sim, uma construção social; e (d) a importância atribuída às singularidades e às práticas sociais cotidianas como forma de constituição da história (Souza \& Costa, 2013, p.8).

Enquanto a história tradicional adotava documentos oficiais, pois seus dados eram passíveis de serem comprovados, garantindo credibilidade à pesquisa, os adeptos da nova história postulam que essa restrição serviria a contar a história dos grandes feitos pelas ilustres figuras, cabendo ao resto da humanidade um papel secundário, e não possibilitando a compreensão das atitudes dos opositores. É por este motivo que o "pesquisador deve se valer de argumentos e evidências históricas de diversas origens e de

Ao referir-se à organização, utilizou-se a sigla LEGO para preservar o diferentes camadas sociais de acordo com cada pesquisa" (Fontoura, Alfaia \& Fernandes, 2013, p.91).

Outra característica da nova história identificada nesta pesquisa é a atenção voltada aos coletivos, tendências e acontecimentos ao invés do foco nas ações dos indivíduos, bem como a noção de que não é possível olhar para o passado sem um ponto de vista próprio, sendo uma visão irrealista aquela que considera que os fatos são apresentados como acontecem, como dado objetivo, neutro e fidedigno (Fontouraet al. 2013).

Godoy (2006) argumenta que muitos problemas de pesquisa que utilizam estudos de caso surgem de situações cotidianas e do desejo do pesquisador de estudar uma situação a partir da prática. Esses problemas procuram responder a questões sobre processos, por que e como as coisas acontecem, assim como questões que buscam descrever e interpretar o que aconteceu em dada situação.

Por isso, o estudo de caso foi escolhido como um guia para se chegar à compreensão da problemática de pesquisa. Trata-se de um caso único, singular, não acessível a todos os pesquisadores, em que emergiu o fenômeno social engendrado em um contexto específico, delimitado espaço-temporalmente (Stake, 1994). Por envolver o fator humano, está distante da possibilidade do estabelecimento e controle de variáveis, o que justifica a abordagem qualitativa. Barros e Carrieri (2015) defendem uma produção de saber nos Estudos Organizacionais que, calcada na relação entre história e cotidiano, possibilite constituir um contraponto às teorias hegemônicas estadunidenses.

A partir das premissas ora apresentadas, a pesquisa qualitativa com diferentes fontes de dados foi adotada. O enfoque no testemunho oral, em contraposição à adoção de apenas documentos oficiais, se deu por meio da realização de 13 entrevistas semi-estruturadas no segundo semestre de 2014. Foram considerados os seguintes critérios para a seleção dos entrevistados: forma de participação no GRUPO e tempo de trabalho na organização, conforme Figura 1. Esses critérios possuem limitações na tentativa de compreender a realidade, mas foram necessários no sentido de possibilitar um recorte à pesquisa. Trabalhadores que não participam do GRUPO, terceirizados, de recrutamento amplo, estagiários e adolescentes trabalhadores, bem como gerentes operacionais, gerentes gerais, diretores e políticos também fazem parte dessa realidade, mas não foram incluídos na pesquisa.

anonimato e o sigilo na pesquisa.

iiAo referir-se ao grupo de discussão, utilizou-se o nome GRUPO para preservar o anonimato e o sigilo na pesquisa. 
Figura 1 - Classificação Final dos Entrevistados

\begin{tabular}{|c|c|c|c|}
\hline 1. a Geração & 2. ${ }^{a}$ Geração & 3." Geração & \\
\hline Entrevistadx 9 & & & Criadores ou primeiros usuários do "GRUPO" \\
\hline \multirow[t]{2}{*}{ Entrevistadx 7} & & $\begin{array}{l}\text { Entrevistadx } 1 \\
\text { Entrevistadx } 4 \\
\text { Entrevistadx } 8 \\
\text { Entrevistadx } 10\end{array}$ & Os que publicam no "GRUPO" \\
\hline & $\begin{array}{l}\text { Entrevistadx } 2 \\
\text { Entrevistadx } 3 \\
\text { Entrevistadx } 5\end{array}$ & $\begin{array}{l}\text { Entrevistadx } 6 \\
\text { Entrevistadx } 11\end{array}$ & Os que recebem e-mails do "GRUPO", mas não publicam \\
\hline $\begin{array}{l}\text { Entrevistadx } 12 \\
\text { Entrevistadx } 13\end{array}$ & & & $\begin{array}{l}\text { Aqueles que conhecem o "GRUPO", mas não participam } \\
\text { dele }\end{array}$ \\
\hline
\end{tabular}

Fonte: Elaborada pela autora.

Além das entrevistas, foram coletados dados secundários para análise documental. Tendo em vista a possibilidade dialógica e o advento das novas tecnologias, foram coletados e-mails trocados no GRUPO, durante o período de um ano, e e-mails mais antigos guardados por um entrevistado que me foi disponibilizado para esta pesquisa, permitindo a análise de períodos recentes e remotos, respectivamente, além do cruzamento de dados provenientes de diversas fontes em cada período histórico. Acredita-se que utilizar tais dados como fontes de dados de pesquisa seja um dos aspectos originais neste artigo e figura como um de nossos desafios, mas também uma das contribuições metodológicas para os Estudos Organizacionais. O uso da internet faz parte do cotidiano de muitos sujeitos, mas não tem sido objeto de relevância nas pesquisas acadêmicas enquanto possibilidade metodológica. Também foram utilizados relatórios, boletins e reportagens diversas como dados secundários que me auxiliaram na compreensão dos discursos oficiais e conhecimentos legitimados nesse contexto social.

Por fim, foram realizadas observações não sistematizadas a fim de desenvolver uma análise genealógica das condições de emergência do GRUPO na LEGO. Percebeu-se que muitas pessoas se recusaram a participar, principalmente no grupo de trabalhadores com menos tempo de casa, mas também alguns aposentados que foram considerados polêmicos pelos participantes; que algumas pessoas pediram para não registrar a conversa; que a maioria questionava se a entrevista seria realmente anônima e como os nomes seriam tratados na pesquisa. Outras sentiram a entrevista como um momento terapêutico e desabafaram angústias, outros reviveram memórias de outras fases da vida que julgaram ter relação com o GRUPO, como lembranças da ditadura e, por fim, foi observado que as pessoas que já conheciam a entrevistadora se abriram mais, enquanto aquelas que ainda não a conheciam buscavam as palavras certas em alguns momentos da entrevista.

É importante ressaltar que as entrevistas foram realizadas em salas reservadas, contudo nos próprios ambientes de trabalho. Assinala-se que tais acontecimentos reproduzem a ideia do GRUPO como tabu, como algo do qual não se pode dizer. Reflete e reproduz também a existência do medo e da dominação no ambiente organizacional. Acredita-se que tais características são as principais do cenário de pesquisa e serão detalhadas nas seções seguintes.

Para análise dos dados, argumenta-se que esta pesquisa é também uma construção narrativa, a qual exige seleção de personagens e lugares (orientação), ações e interações (ação complicadora), significação do que aconteceu (avaliação) e desfecho (solução) (Zaccarelli \& Godoy, 2013). Corrobora-se aqui com os argumentos de Zaccarelli e Godoy (2013) que, ao estudarem as possibilidades de uso de narrativas nas pesquisas em organizações, ressaltaram que contar histórias envolve uma relação entre narrador e audiência, na medida em que aquele seleciona, organiza, conecta e avalia eventos como significativos para estes, mesmo sabendo que não houve uma cronologia linear e homogênea nem nos acontecimentos nem nas análises. Portanto, a maior parte das entrevistas foi utilizada na construção dessa narrativa e não foram apresentados trechos para preservar o anonimato dos sujeitos de pesquisa, já que essa foi uma preocupação recorrente durante a coleta de dados.

Entremeando a construção narrativa, recorreu-se a elementos da Análise de Discurso Crítica (Fairclough, 2001; 2003) em momentos pertinentes para aprofundar a análise da construção dos personagens e de discursos legitimadores e transformadores, pois se utiliza a noção de discurso como prática social (Fairclough, 2001). Alguns desses elementos possibilitaram a análise de gêneros (modos de ação), estilos (modos de identificação) e discursos (modos de representação) (Fairclough, 2003), mesmo que tais nomenclaturas estejam silenciadas na análise na intenção de preservar a legibilidade da construção narrativa.

Nessa bricolagem entre construção narrativa e análise de discurso crítica, buscou-se seguir as orientações de Foucault (2010): é necessário escolher os materiais de análise em função dos dados do problema (ao invés de fazer um tratamento exaustivo de todo o material); deve-se focar nos elementos que possam resolver o problema, traçando, com esse objetivo, as relações entre eles (haverá ausências nas análises, mas em uma avaliação é preciso se questionar se elas seguem os princípios primeiros definidos pelo pesquisador quanto ao problema e a sua solução). A estrutura desta pesquisa foi pensada, então, de forma a resolver o problema colocado, a partir da escolha tanto de dados quanto de 
relações entre elementos que julguei necessárias para a sua solução (o que não impede uma leitura diferente do(a)s leitor(a)s).

\section{Discussão e Análise de Dados}

\section{Contextualização: Neoliberalismo e Nova Gestão Pública}

Compreender o GRUPO e sua história é também compreender a história da sociedade em que ele emerge; apreender os seus regimes de verdade é perceber como relações de poder são sustentadas e reproduzidas. Para tanto, analisou-se artigos científicos, pesquisas, reportagens e entrevistas que, de alguma forma, foram fontes para o esboço deum panorama da década de 1990. Além disso, foi possível também identificara articulação de diversos discursos, como o científico, o econômico, o social, o da mídia e o legal, que formaram uma relação poder-saber característica da época.

Foucault (2013a; 2013b) enfatiza em seus estudos a historicidade dos fenômenos e a construção de regimes de verdade que permeiam cada um deles. Se a verdade é "um conjunto de procedimentos regulados para a produção, a lei, a repartição, a circulação e o funcionamento dos enunciados", o regime da verdade é a ligação entre verdade e sistemas de poder, "que a produzem e apoiam, e a efeitos de poder que ela induz e que a reproduzem" (Foucault, 2014, p.54). Para Foucault (2013b), a evolução que a história tradicional sugere não é natural, pois é construída discursivamente.

Portanto, ao desenvolver a história do GRUPO, acredita-se que tanto a discussão quanto a própria história não acontecem fora das relações de poder-saber; estão imersas em um contexto social, cultural e histórico que restringe o que é verdadeiro e o que nem é digno desse sistema de classificação; diz o que é "científico" e o que não é; o que é "Administração" e o que não é. E essas relações de poder-saber também fazem parte do cotidiano nas organizações, incluindo as práticas de resistência. Afinal, por que uma prática é considerada resistência? Justamente por existirem práticas não resistentes em um espectro normal-anormal. E a legitimação dessas práticas não resistentes - consideradas "normais" em ambientes de trabalho - é atravessada pelas relações de podersaber que condicionam o que é "a ciência administrativa". E tal condicionamento não acontece naturalmente, ele é histórico. Portanto, denominei o Neoliberalismo e a Nova Gestão Pública como condições de emergência do GRUPO.

Anderson (1995) argumenta que o pensamento neoliberal surge depois da Segunda Guerra Mundial em combate às ideias keynesianas intervencionistas, mesmo não tendo tido muita expressão na época. Com a crise do capitalismo da década de 1970, os neoliberais ganharam terreno propondo como remédio à crise a manutenção de um Estado forte, mas apenas para romper com o poder dos sindicatos, com a criação de um exército de reserva de trabalho, e para controlar o dinheiro, com reformas fiscais que incentivassem os agentes econômicos pela redução dos impostos sobre os rendimentos mais altos. Assim, os investimentos keynesianos e a regulação produção-consumo pelo Estado deram lugar à contenção de gastos com bem-estar e a "uma nova e saudável desigualdade [que] iria voltar a dinamizar as economias avançadas" (Anderson, 1995, p.10), sendo esta a política neoliberal respaldada tanto em universidades quanto na política, nos governos Thatcher (Reino Unido) e Reagan (Estados Unidos) (Paes de Paula, 2005b).

Segundo Paes de Paula (2005b), o neoliberalismo conseguiu fornecer respostas à crise do mesmo modo que Keynes ofereceu alternativas em 1929. Aos poucos, as ideias tornaram-se aceitáveis naquele período e integraram nova agenda para o mundo do trabalho. No Reino Unido, Thatcher consolidou o declínio do sindicalismo, a desregulamentação da legislação trabalhista e a flexibilização dos direitos sociais. $E$ tais influências não se restringiram às empresas privadas, formando as bases de um novo modelo de gestão pública.

Para aumentar a eficiência administrativa do Estado, Thatcher reduziu o tamanho da máquina e seu custo, e para garantir transparência e clareza, foram instalados sistemas de informação gerencial computadorizados. Como tais medidas foram insuficientes para a reforma desejada, foi criado um novo programa, - Next Steps, que mudou as características da Administração Pública até então conhecida e buscava, em resumo, usar ideias e ferramentas gerenciais advindas do setor privado. Em direção semelhante, nos Estados Unidos, Osborne e Gaebler argumentavam em "Reinventando o governo" sobre a substituição de um modelo burocrático por um modelo gerencial (Paes de Paula, 2005b).

O gerencialismo foi um movimento encabeçado por "gurus" da Administração que, ao criticar a base da administração burocrática como a formalidade, a impessoalidade e o burocrata profissional (Secchi, 2009), passaram a defender a noção de organização pósburocrática que teria como essência as ideias de flexibilidade e participação. Baseia-se também nas crenças de atrelamento do progresso social à produtividade econômica, da defesa do aumento de produtividade pelo uso de tecnologias de organização e informação sofisticadas, do ideário de uma força de trabalho disciplinada para aplicação dessas tecnologias, do management como tendo papel crucial no planejamento em vista da produtividade e do direito de administrar que os gerentes possuem (Paes de Paula, 2005b). Secchi (2009) faz uma síntese: é um modelo de gestão que se fundamenta nos valores de eficiência, eficácia e competitividade.

Conforme Brulon, Obayon e Rosenberg (2012), o Brasil passou por três modelos de reformas na administração pública (patrimonialista, burocrática e gerencial), sem que nenhum deles tenha sido abandonado por completo. As inovações com base no modelo burocrático iniciam junto com a República Nova, em 1930, momento marcado por conquistas sociais como o voto secreto, o direito de voto para as mulheres e as leis trabalhistas (Capobiango, Nascimento, Silva, \& Fatoni , 2013). Observou-se o fortalecimento da burocracia, com estatutos normativos e órgãos normativos e fiscalizadores (Lima Júnior, 1998), em detrimento da administração patrimonialista (característica das monarquias absolutistas nas quais o patrimônio público e o privado eram confundidos) (BresserPereira, 1996). 
Para Bresser-Pereira (1996), os defeitos da administração burocrática como lentidão, alto custo, baixa qualidade e autorreferência não eram tão graves quando o Estado era pequeno. Com o seu crescimento, tanto em funções sociais quanto econômicas, o problema da ineficiência passou a destacar-se. Somando isso à crise mundial nos anos 1970 e à crescente aderência que tiveram as ideias da administração pública gerencial desenvolvidas no Reino Unido e nos Estados Unidos, BresserPereira (1996) acredita que se foi delineando os contornos na nova administração pública também no Brasil.

Brulon, Obayon e Rosenberg (2012) chamam atenção para uma onda de reformas após a publicação da Constituição, de 1988.
Em busca na base de dados da Revista de Administração Pública, listei na Figura 2 alguns assuntos pesquisados do final da década de 1980 a meados da década de 1990. Percebi nos títulos dos artigos uma preocupação constante com reformas que pudessem melhorar a administração pública a partir do discurso do movimento gerencialista, como "cliente", "modernizar", "autonomia de gestão", "concorrência", "novas formas de gestão", "pós-fordista", "microinformatização", "solução", "mérito", "heróis", "empreendedor", "sistemas de informação" e "filosofia da qualidade". Mas essa preocupação não era só acadêmica.

Figura 2 - Assuntos pesquisados do final da década de 1980 a meados da década de 1990

\begin{tabular}{|c|c|c|}
\hline ANO & AUTOR(ES) & TITULO DO ARTIGO \\
\hline 1984 & Rossi Augusta Alves Corrêa & A imagem do cliente e do servidor público: perspectivas para melhorá-la \\
\hline 1986 & José Martins da Silva & $\begin{array}{c}\text { Notas sobre a relevância da elaboração de um novo texto constitucional } \\
\text { para a efetividade da democracia no Brasil }\end{array}$ \\
\hline 1987 & Reginaldo Souza Santos & Interesse público e interesse privado \\
\hline 1987 & Paulo Roberto Motta & $\begin{array}{c}\text { Modernização administrativa: propostas alternativas para o estado } \\
\text { latino-americano }\end{array}$ \\
\hline 1988 & Ruy de Alencar Matos & Para que modernizar a organização pública? \\
\hline 1988 & João Benjamin da Cruz Júnior & $\begin{array}{l}\text { Organização e administração de entidades públicas: aspectos políticos, } \\
\text { econômicos e sociais de um paradigma emergente }\end{array}$ \\
\hline 1990 & Marcos Guedes Veneu & Representações do funcionário público \\
\hline 1993 & José Paulo Zeetano Chahad & $\begin{array}{l}\text { Recursos humanos e gastos com pessoal no setor público brasileiro: } \\
\text { recomendações de políticas }\end{array}$ \\
\hline 1994 & Pedro Lincon Mattos & $\begin{array}{l}\text { Racionalização administrativa versus concepções patrimonialistas no } \\
\text { provimento de pessoal no serviço federal: o Ministério da Educação e } \\
\text { Cultura entre } 1960 \text { e } 1985\end{array}$ \\
\hline 1994 & Carlos Eduardo de Souza e Silva & $\begin{array}{l}\text { Autonomia de gestão e concorrência: em busca de novas } \\
\text { formas de gestão do setor público em um contexto pós-fordista }\end{array}$ \\
\hline 1994 & $\begin{array}{l}\text { Henrique M. R. de Freitas } \\
\quad \text { Joio Luiz Becker } \\
\text { Candido Fonseca da Silva }\end{array}$ & Microinformatização e caos organizacional: uma solução \\
\hline 1996 & Luiz Carlos Bresser Pereira & Da administração pública burocrática à gerencial \\
\hline 1996 & Istvan Karoly Kasznar & $\begin{array}{l}\text { Identificação das diversas atividades desempenhadas por } \\
\text { administradores públicos profissionais na gerência dos sistemas de } \\
\text { mérito }\end{array}$ \\
\hline 1996 & Pedro Paulo Carbone & $\begin{array}{l}\text { Os heróis do setor público: a teia cultural engolindo } \\
\text { o empreendedor }\end{array}$ \\
\hline 1997 & $\begin{array}{l}\text { Marlei Pozzebon } \\
\text { Henrique M. R. de Freitas }\end{array}$ & $\begin{array}{l}\text { Por um conjunto de princípios que possibilitem a construção de novos } \\
\text { modelos de sistemas de informação }\end{array}$ \\
\hline 1997 & Ricardo Corrêa Gomes & $\begin{array}{l}\text { Análise exploratória da perspectiva de implantação da } \\
\text { filosofia da qualidade na administração pública }\end{array}$ \\
\hline
\end{tabular}

Fonte: elaborada pela autora

No governo de Fernando Henrique Cardoso - FHC (1995-2002) -, Bresser-Pereira foi indicado para dirigir o Ministério da Administração e Reforma do Estado (MARE). Apesar de BresserPereira (1996) diferenciar o que seria uma proposta de reforma neoliberal (retirada do Estado da Economia) de uma proposta social democrática (aumenta a governança do Estado), quando se trata da dimensão administrativa, ambas partem dos pressupostos gerencialistas explicitados anteriormente, principalmente, da adaptação de práticas de gestão privadas para o setor público.

De forma geral, existem três dimensões abarcadas na reforma proposta, sendo elas a dimensão institucional-legal, a cultural e a gestão. A primeira refere-se à criação ou modificação da Constituição, de leis e regulamentos. Já a segunda trata-se da tentativa de acabar com as práticas patrimonialistas que, além de condenação moral, precisam ser punidas. Por fim, a dimensãogestão relaciona-se com as práticas preconizadas pelo movimento gerencialista, com vistas à diminuição do custo do serviço público cujo controle e qualidade seriam melhores (Bresser-Pereira, 1996).

Segundo Paes de Paula (2005a, p. 38), para atingir os objetivos propostos no novo modelo de gestão, dever-se-ia "enfatizar a profissionalização e o uso de práticas de gestão do setor privado". Contudo, a autora vê com ressalvas essa proposta, pois ela não incorpora uma dimensão sociopolítica, que seria a participação dos 
cidadãos nos processos decisórios, e, por partilhar do esquematismo gerencialista, "dificulta o tratamento da relação entre os aspectos técnicos e políticos da gestão" (Paes de Paula, 2005a).

Toda essa discussão ilustra uma estreita relação entre o saber científico que busca legitimar o neoliberalismo como regime de verdade de uma época por meio do discurso da administração gerencial, configurando uma relação poder-saber. E o discurso da administração gerencial também consiste em práticas defendidas no governo FHC, que consubstanciaram uma ampla reforma gerencial, por sua vez legitimada pelo Direito com a inclusão do princípio da eficiência (Emenda n.o 19/1998) na Constituição Federal de 1988.

Entretanto, tais regimes silenciam críticas. Analisando o neoliberalismo na América Latina, Ibarra (2011) o considera como uma utopia que difundiu no Terceiro Mundo a promessa de que o jogo livre dos mercados fecharia a brecha do atraso por meio da abertura de fronteiras, da estabilização de preços e contas públicas. Seria utopia, pois apresenta uma série de consequências negativas e falácias como a ampliação da brecha do atraso da África e da América Latina, a tentativa de isenção do fisco de obrigações transferindo riscos do Estado às famílias, escassos avanços na correção de desigualdades e aumento da pobreza que ocasionam problemas de outras ordens a partir da concentração de poder econômico e político, uma dinâmica de emigração que conduz à precarização dos direitos laborais, o fracasso das privatizações, entre outras questões (Ibarra, 2011).

Assim, silenciam também as diferenças entre o liberalismo clássico e neoliberalismo. Para Pereira (2004), ambos tinham em sua base valorativa a noção de liberdade. Contudo, devido às diferenças históricas, o autor considera o primeiro como revolucionário e o segundo como reacionário. Enquanto o liberalismo contribuiu para a derrocada do modo de produção feudal, o neoliberalismo contribui para acentuar a concentração de renda e a exclusão social. Além disso, questiona essa noção de liberdade que enfatiza a dimensão econômica e relega ao segundo plano a dimensão política, pois acredita que a concentração de poder econômico gera concentração de poder político, o que fomenta uma situação de não liberdade, o que vai ao encontro das críticas de Paes de Paula (2005a) no âmbito da gestão. Considerase que tal contexto de análise macro caracteriza as condições de emergência do GRUPO na LEGO e são fundamentais para a compreensão das relações de poder e resistência engendradas nessa história

\section{Uma história de resistências: da resistência combativa à normalizada}

Ao final da década de 1990, atendendo à aclamada reforma do Estado, à demanda por eficiência e modernização, os gestores da LEGO partiram para a ação, entendendo como resposta para muitos problemas apontados a informatização. Entretanto, desde o início da instalação de computadores, o sistema de e-mails funcionava de forma rudimentar. A complexificação e a profissionalização do sistema utilizado na organização aconteceu em meados de 1990, quando, em parceria com uma universidade federal - até então a internet estava sendo desenvolvida de forma restrita nas instituições de pesquisa e universidades - a LEGO informatizou as suas atividades e proveu maior acesso à internet aos trabalhadores para a consecução de seus trabalhos.

Para que tal mudança fosse incorporada no cotidiano dos trabalhadores, foram criadas diversas listas de discussão no intuito de se incentivar o uso dos e-mails. É possível perceber a luta entre dois grandes discursos no cotidiano dessa época: a ineficiência burocrática, que trazia consigo a figura do funcionário públicoiii, que se perde em meio a tanta papelada e cafezinhos, e a informatização como promessa de celeridade, profissionalização, eficiência.

A criação das listas de discussão na LEGO, como a lista de anúncios e a lista de assuntos relativos aos trabalhadores - esta ficou conhecida como GRUPO - deve ser entendida a partir das suas condições de emergência. Estas, por sua vez, entremeiam o saber científico da Administração (planejamento e gestão), da Administração Pública (gerencialismo) e do Direito (reforma do Estado e inclusão do princípio da eficiência na Constituição Federal) constituindo uma relação poder-saber. Como efeitos produzidos a partir dessa relação, pode-se citar a existência da representaçãomatriz dos funcionários públicos e da demanda por modernização/informatização como regimes de verdade. Nesse último caso, observa-se que o gerencialismo contou com a incitação econômica advinda do discurso neoliberal na década de 1990 e a participação da mídia e de instituições de ensino, como escolas de Administração que importaram suas metodologias e valores dos Estados Unidos (Serva, 1992).

Se o GRUPO tinha uma lista de assuntos diversos de interesse dos trabalhadores, como delimitar o que é de interesse deles? Reivindicações de pautas trabalhistas? Denúncia de assédio moral na organização? Discussões sobre visões político-filosóficas? Talvez a melhor pergunta fosse: quais processos de subjetivação engendram esse trabalhador que pretende participar de discussões no GRUPO?

Para contextualizar, em termos de direção, a LEGO possui duas instâncias: política (gabinetes) e administrativa (secretaria). $\mathrm{Na}$ primeira, existem os mandatários de cargos eletivos - aqui denominados como "políticos" - que nomeiam livremente, sem necessidade de concurso, os trabalhadores de recrutamento amplo. $\mathrm{Na}$ última, há trabalhadores do quadro permanente (efetivos), dentre os quais são escolhidos diretores e gerentes (recrutamento limitado). Essa separação entre área política e técnica apareceu no final da década de 1980, sustentada por um discurso oficial de que a sociedade tinha uma imagem depreciativa do político, do funcionário público e da LEGO, além dos políticos não estarem satisfeitos com os serviços que the eram prestados, e que tal ineficiência era justificada pelo fato de se tratar de uma "Casa Política". 
iii Em seus estudos, Veneu (1990) encontrou uma representação-matriz do funcionário público, remetendo-a a canções de 1952, e ainda se faziam presentes no momento analisado. Eram dois personagens: a alta funcionária, que ascende por relações pessoais e apadrinhamentos, e o funcionário de

Figura 3 - Casa Política x Eficiência

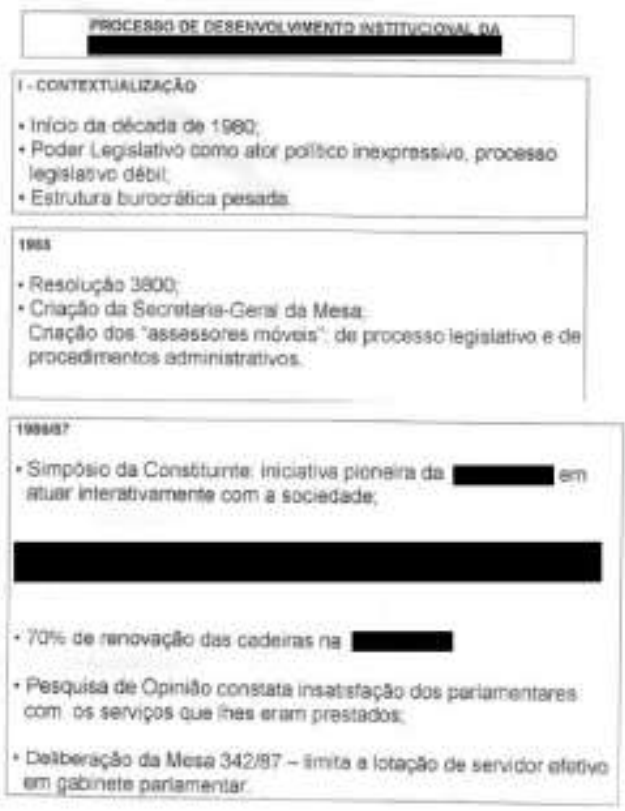

pequeno escalão, que resume suas atividades diárias em tomar cafezinho e ler jornal. Ambos, apesar da diferença hierárquica, teriam em comum o fato de pretenderem ganhar dinheiro sem trabalhar.

\section{Fonte: Arquivo pessoal}

Percebe-se que há uma interdiscursividade entre o discurso organizacional da ineficiência dos funcionários públicos e alguns discursos veiculados na mídia naquela época, como a caça aos marajás. As Figuras 4 e 5 são trechos de uma reportagem veiculada na Revista Veja, no dia 23 de março de 1988, com o título "A guerra ao turbante".

Figura 4 - Discurso de Caça aos Marajás - Parte 1

\begin{tabular}{|c|c|c|}
\hline 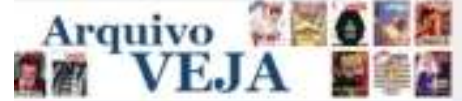 & noperopen & mapenase caps \\
\hline
\end{tabular}

Reportagens

\section{A guerra ao turbante}

No seu papel de caesador de marajess. o alagoano Fernando Collor de Mello torna-se um dos governadores mais populares do paess

E defici encontraf ie um brasleiro com diplema universidino que saiba de

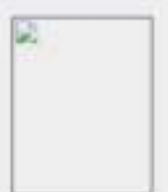

cor o nome de todos ns povernadares estaduais, mas e improvivel descobrit-se alquen que náo so bentre do nome de governader de Alagoas: Desde que foi eleito, Fernando color de Mello, 38 mas, sem assinar uma unica jrinde obra em seu fstado, conquistou a simpatia doe

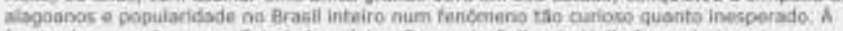
frente da segundo menor fstado brasileiro, Fernondo Collor De Metilo foum hoje entre os: governadorac mais festojadoe do pais - soum asperava ver Waidtir Nires, da Bahia, ou Miguel

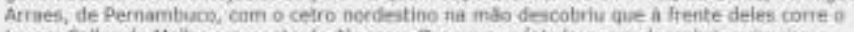

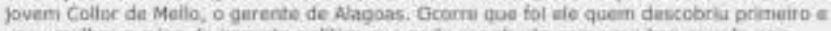
ussos methor a mina de unparto politico que pode ser aberta com umi boa caçada aos. marajas de servico pablico. Essa for swa obra o esse e o sea segredo.

Num Estade en que doì- leccos da pepulocho têm de viver com mienas de 13000 crutados.

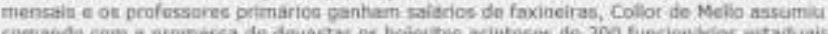

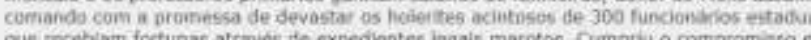
que roceblam fortunar atrives de expedientes iegais marotos. Cumprivi o comprominto e

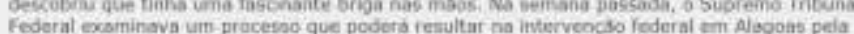

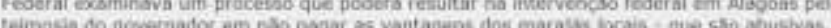
mas tem o resgaldo da lé.

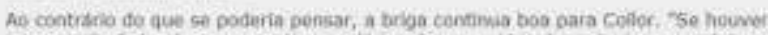
intervencba federal para garantir os salaries dos manajas, ele podera ser o proxino presidente da Repoblica", pievo o senador TeotÓnio vileia Fillo, de PMob alaposno, mesmo partido de Collos, com ovem mantem relaçoes apeoas sofriveis. Na axalloço de vilola, ums intervencac en Alagoas debarts calior na posic5a canfartavar de um paiadino da moralidade contra quem

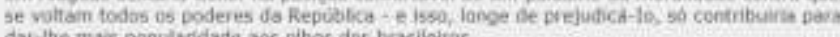
dar the mes populsridade ans pihos das brasileiras

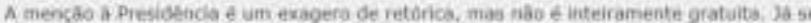

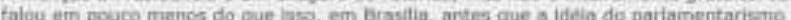

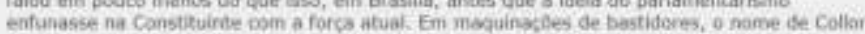
chepou a ser cogtado como canchidoto a vike-grecicente nums chapo encrabecoda peilo chefo

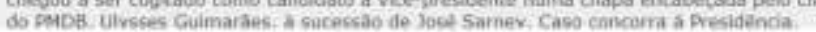

Fonte: Revista Veja (1988) 
Figura 5 - Discurso de Caça aos Marajás - Parte 2

MARAJÁ CANAL HA - Na Bahia, o governador Waldir Pires, impulsionado pelos mesmos objetivos saneadores de Collor de Mello, fez publicar no inicio do més uma lista com os nomes de 349 servidores publicos que recebem os mais altos salarios na administraça estadual alguns deles com vencimentos de até 800.000 cruzados. A essa lista Pires acrescentou um decreto que limita a remuneraçăo do funcionário publico baiano ao que ganha um secretário de Estado, 380.000 cruzados. "Resolvemos dar um basta porque a coisa estava chegando a ameacar o decoro", esclarece o governador.

O problema é que entram na lista pessoas como o procurador aposentado Calmon de Passos 68 ano5, ex-5ecretario da Fazenda, ex-presidente da secão local da Ordem do5 Advogados do Brasil e um furista respeltado. Passos ganhava, antes dos cortes, 485.175 cruzados mensais, um nivel de proventos compativel com a carreira que fez. 0 procurador, obviamente, năo $f$ um maraja, mas entrou no combolo e pagou caro. Equiparado na relação aos funcionários aproveitadores que formam o marajanato balano, ele chegou a ser acordado de madrugada por telefonemas ameaçadores, em que fol chamado de marajä "canalha" e "ladrăo". "A decisáo de cortar salários exagerados e justa, mas a forma pela qual se efetuou esse corte $e$ injusta, maldosa, desieal", diz Pas5os, que em duas oportunidades fol convidado a participar da administração Waldir Pires. "Para mim, o governador Pires morreu, é um defunto", afirma o procurador.

SERVIDORES MEDIOCRES - A tendência a confundir salários condignos com marajanato revela a hipocrisia que acompanha a discussän desse tema no pais atuatmente. $f$ obvio que nāo se chegara a lugar algum com a limitaçăo indiscriminada de salários só porque os cofres públicos estảo sobrecarregados ou ainda por uma atençăo com os servidores mais humilides que recebern dois salários minimos. Se o dinheiro é suficiente apenas para pagar 35.000 cruzados a um diretor de hospital ou a um engenhelro da Petrobras - se os quadros continuarem se expandindo na velocidade atual, è possivel que se chegue a essa situaçào *, a saida será encurtar a área de açāo do Estado e năo manter servidores mediocres na folha. Engana-se quem classificar como marajá o desembargador que ganha 500.000 cruzados por mẻs, porque ele é o melhor especime de uma profissão, precisa manter um padrăo de vida a altura do seu cargo, deve garantir o mesmo nivel para seu fitho e, finalmente, nå é bom que, lidando com causas de milhóes de cruzados, seja tentado a procurar uma fonte de rendimento extra fora da profissso.

Maraja e o funcionario que ganha muito através de ardis legals, como os coronéls da PM de São Paulo, que chegam ao fim do mês com vencimentos quatro vezes maiores que os de seus colegas, ou é o funcionálio que tem um cheque razoavel sem fazer nada, como acontece em tantos caso5. No gabinete do prefeito Sérgio Ferrara, em Belo Horizonte, o cidadäo Arthur Cavaicanti Agular ganha 315.000 cruzados para introduzir visitantes e servir cafezinho. A rigor, Aguiar arrecada apenas 45,000 cruzados na prefeitura, mas deram-lhe um cargo extra, o de vice-presidente da Prodabel, a empresa que processa informaçós para o municipio, de onde ele arranca mensalmente 270.000 cruzados sem dar expediente. Assim, num caso que concentra todos os males do marajanato, Aguiar usa turbante colorido com um salario inferior ao do Jurista balano Passos, que ndo usa. Em Minas pode-se lembrar ainda o caso dos secretários estaduais Euripedes Craide, da Administraçăo, e Tancredo Naves, de Esporte, que acumulam seus vencimentos nestes postos com os de deputados estaduals e tiram 1,1 milhầo de cruzados por més.

Na sua intençăo de sanear a administraçăo alagoana, livrando-se de uma chaga antiga, o governador Collor de Mello acabou, no entanto, numa situaço em que se torna agente de um erro ao justificar uma desobediencia a Justiça com o argumento de que age em nome do bem. A Justica, qualquer que seja a opiniâo de cada um sobre suas decisōes, existe para diminuir conflitos em ültima instância e nada deve substitui-la nessa tarefa.

Fonte: Revista Veja (1988)

Enquanto a Figura 4 constrói positivamente o personagem "caçador de marajás", na Figura 5 o produtoriv tenta (des)construir o que seria a figura do marajá. Para ele, não basta ter altos salários para ser considerado parte de um marajanato. Observa-se, novamente, a interdiscursividade, dessa vez para a retomada do discurso da meritocracia como sistema de crenças. Se o funcionário for um desembargador, ele

precisa manter um padrão de vida à altura de seu cargo, deve garantir o mesmo nível para seu filho e, finalmente, não é bom que, lidando com causas de milhões de cruzados, seja tentado a procura uma fonte de rendimento extra fora da profissão. (Revista Veja, 1988)

Entretanto, se a função do funcionário for "introduzir visitantes e servir cafezinho" ele ganha a alcunha de "servidor medíocre", o que caracteriza uma identificação inferior e distante de quem fala com o uso do diminutivo.

Percebe-se que, na luta para defender certas pessoas e interesses, algumas questões são silenciadas. Por que os filhos de outros funcionários não precisam ter seu nível de vida garantido? Será que isso é representativo de uma sociedade desigual que dificulta ascensões sociais e prima pela manutenção do status quo? Seria a confirmação do dito popular "Filho de peixe, peixinho é"? E por que aconselhar ("não é bom que") que o desembargador não seja tentado? É a objetivação do "jeitinho brasileiro"? Dessa forma, considera-se que o discurso oficial que sustentou a modificação na organização do trabalho na LEGO, separando instâncias política e administrativa, estava inserido em uma luta discursiva e de poder mais ampla.

A separação política e administrativa, para alguns trabalhadores, ainda possui outra versão: até então, o efetivo trabalhava diretamente nos gabinetes dos "políticos", independente de posturas político-ideológicas. Por diversas vezes, tal situação causou constrangimentos em trabalhadores, pois eles tinham um chefe direto - o político - que poderia agir em nome de interesses individuais, particulares ou de um grupo de influência, sendo contrário ao que prega o Direito Administrativo sobre o interesse 
público e a indiscricionariedade dos atos administrativos, regime de verdade construído na relação desse saber-poder.

Diante disso, foi defendido o fortalecimento da secretaria administrativa que se pautaria em conceitos como produtividade e resultados contando para isso com todos os trabalhadores efetivos. O que se ocultou nessa época era que, mesmo adotando-se premissas gerenciais, a questão política não estaria de fora da gestão. Silenciou-se também que a imagem depreciativa do político e da LEGO pela sociedade não poderia ser alterada apenas com melhorias de práticas relativas aos trabalhadores e à gestão administrativa, sem se discutir o modus operandi do poder legislativo em si (Fuks, 2010).

Apesar dessa diferenciação formal entre gabinetes e secretaria, as relações sociais e de poder se imbricam entre as duas instâncias, o que caracterizou um embate direto entre os gestores da LEGO e os trabalhadores no final da década de 1990. O diretor-geral da LEGO, de 1983 até o final de 1999, mesmo sendo servidor efetivo, era uma pessoa com estreita ligação político-ideológica-partidária com os governantes na época (PSDB). Com a eleição de 1998, houve uma troca de partidos no governo, saindo o PSDB e entrando o PMDB, e isso se refletiu diretamente no cotidiano da LEGO. Primeiramente, por que se mudou toda uma política de provimento de cargos de recrutamento limitado, alterando-se uma regra formalizada para que o cargo pudesse ser ocupado por uma pessoa que não era efetiva na LEGO. Segundo, por que todo esse momento de transição política e administrativa estava sendo bastante discutido na mídia, agravados por escândalos midiáticos sobre altos salários. Muitos participantes do GRUPO eram a favor da mudança, pois criticavam uma gestão de tantos anos do antigo diretor-geral. Mas também havia aqueles trabalhadores mais ligados à antiga gestão que eram contra essa mudança.

sujeito, mas todo o complexo discursivo que envolve os discursos ali veiculados.

Alerta-se o leitor que se atente às condições de produção, distribuição consumo de textos específicos da Revista Veja, de circulação nacional. Portanto, quando se diz "produtor" ou "quem fala" não se refere ao

Figura 6 - Discussões no GRUPO no final da década de 1990

Mensagem 2

De: clara@lego.br

Para: servidor@lego.br

Assunto: RES: Nova forma de trabalhar

[João],

Não tenho o que desculpar. Tudo é enriquecedor. Eu na verdade revoltei-me com a pecha de 'elite' e quis apontar que elite, em termos de privilégios, são outras áreas da Casa. Concordo com o seu raciocinio int eiramente.

Desculpe mas estou bastante chateada hoje, sentindo que nós fomos achincalhados com esse retorno das Shoras!

Não valemos nada pra esse pessoal podre que temos que conviver aqui dentro.

Abraços da [Clara].

Mensagem 3

De: rogerio@lego.br

Para: servidor@lego.br

Assunto: RES: Nova forma de trabalhar

Prez ados colegas,

acabei de ter os informes da reunião sobre a jornada através da [Cláudia]. Gostaria de propor, para avaliação pelo colegiado, que o [Henrique] convoque uma assembleia geral dos servidores da Secretaria, para o Teatro ou Espaço Popular.

Est ão fazendo de nós fantoches nesta guerra de vaidades e de poder. Temos que mostrar nossa mobilização. Se acham que a imprensa vai cair de pau em cima da gente, que venha nos entrevistar que poderemos mostrar o que realmente está prejudicando a imagem da LEGO. Até parece que a implantação prejudica tanto a imagem da Casa. Principalmente ouvindo isto de quem ajudou a implantar e não fez nada à época. Agora quer colocar este desgaste para a atual estrutura. Não ares entam dados, não discutem com os servidores como prometido.

Caso eles não dêem o prazo de 30 dias para a discussão com os servidores, temos que fazer a assembleia geral e buscar uma mobilização levantando a bandeira da falta de discussão, prometida pela [gestão poltica], e que não aconteceu.

Mensagem 4

De: camila@lego.br

Para: servidor@lego.br

Assunto: RES: Nova forma de trabalhar

E pensar que eu, ingenuamente, achei que a direção da Casa merecia cumprimentos par ter adiado o fim da jomada flexibilizada.. Como disse o [Cláudio]: esqueçam o que eu disse. Levei 8 meses para começar a pensar na possibilidade de acreditar que alguma cois a mudaria. Só posso rir dos 'defensores da moralidade e da imagem do Legislativo diante da sociedade', tão preocupados, coitados. E quanto ao que a Erika disse, assino embaixo, pois me encontro em situação idêntica. [Camila].

Fonte: dados da pesquisa 
Analisando a troca de e-mails expressa na Figura 6, percebo algumas características do GRUPO nesse período. Nestas três mensagens, há uma densa caracterização do "eu" contra o "outro". Nos trechos "Estão fazendo de nós fantoches", "Se acham que a imprensa vai cair de pau em cima da gente", "Não apresentam dados, não discutem com os servidores como prometido", "Caso eles não deem o prazo", a primeira pessoal do plural "nós" é usada para unificar o grupo que sofre as ações em contraposição a "eles" que é o sujeito agente nas orações. Além de fazer essa separação entre "nós" e "eles", essa relação social é qualificada como uma luta: "Não valemos nada pra esse pessoal podre", "guerra de vaidades e de poder", "ouvindo isto de quem ajudou a implantar e não fez nada à época", "Só posso rir dos 'defensores da moralidade e da imagem do Legislativo diante da sociedade', tão preocupados, coitados".

Nesse jogo de poder, existe uma disputa discursiva sobre a ação de aumentar a jornada de trabalho de seis para oito horas, a qual pode ser vista como um privilégio em comparação com o restante da sociedade e/ou como uma afronta aos direitos dos trabalhadores que já haviam conquistado essa redução de jornada. Nesse campo de batalha específico na LEGO, a criação de um sindicato emerge como estratégia possível para os trabalhadores.

Figura 7 - Criação do sindicato

Mensagem 5

De:carlos@lego.br

Para: servidor@lego.br

Assunto: RES: Deliberação []

Pessoal,

Não digo que fui surpreendido pela Deliberação []. Também não fui surpreendido pela revogação de um artigo de uma deliberação que sequer foi publicada. E assim continua, infelizmente, apesar do princípio da publicidade que rege constitucionalmente o serviço público, inclusive o Poder Legislativo [].

Acho que a única boa resposta à altura que nós, servidores, podemos dar é criar o nosso sindicato. A lentidão que esse assunto caminha realmente me preocupa e desanima.

Carlos.

Mensagem 6

De:1oao@lego.br

Para: servidor@lego.br

Assunto: Sindicato-Palestras de quinta passada

Pessoal,

(...) O [Lucas] falou sobre a oportunidade e a necessidade de constituirmos um sindicato num momento de reformas constitucionais, em que a politica de enxugamento/ desmantelamento do Estado adotada pelo Governo Federal tem sido recebida com uma certa apatia por parte do funcionalismo. Essa apatia está expressa na pouca discussão que as reformas encontraram antes de serem aprovadas, agora já estando em fase de regulamentação. Os servidores federais já perderam alguns direitos - adicional quinquenal, licença-prêmio, promoções (suspensas) -, mesmo com o [nosso governo] na contra-mão dess a politica, a tendência é que as mudanças envolvam os funcionalismos estaduale municipal.

(...) Somos 'servidores da LEGO'; servidores do [nível de governo] são, para nós, os que trabalham no Executivo. Esquecemo-nos de que somos regidos, como eles, pelo mesmo Estatuto dos Servidores [nivel de governo] - ainda que arcaico e carente de revisão. A luta pelo $13 .^{\circ}$ do ano passado no Executivo, por exemplo, simplesmente não nos disse respeito. E, embora as questões internas - [FUNDO DE PREVDÊNCIA 1], assistência médicoodontológica, etc. - sejam de suma importância, deveriamos também ampliar nossos horizontes de discussão e participar das questões externas. Toda essa apatia redunda em uma falta de mobilização muito grande, e até na não consciência de nossos direitos: muitos de nós não sabem, mas é-nos constitucionalmente garantido o direito à greve (embora is to ainda não tenha sido regulamentado), à livre associação e até à participação em politicas de pessoal (ainda que por meio de representantes designados pelos Poderes). Por tudo isso, o [Lucas] considera que a nossa organização formal num sindicato, com representantes atuando sob garantias, é muito importante. Não podemos ficar à sombra de outras categorias, muito mais adiantadas em termos de organização. (..) A experiência da [associação de servidores da LEGO] serve para nos mostrar que tipo de sindicato nós NÃO queremos ter Saímos de uma ordem autoritária, onde o dissenso era coibido e a concessão de direitos era considerada uma esmola: a necessidade do sindicato expressa a própria necessidade de rompimento com uma ordem anterior. Nunca houve, aqui na LEGO, uma possibilidade de discussão como a que vivemos agora, e a criação do sindicato é a forma de preservar is to, dando continuidade à luta(...). Um abraço a todos. [João].

Fonte: dados da pesquisa

As trocas de e-mails expressas referem-se ao período inicial do GRUPO no final da década de 1990. Apesar dessa seleção, havia outras temáticas levantadas, questionadas, argumentadas e criticadas no GRUPO, demonstrando certa fragmentação entre o próprio grupo que se une para resistir à gestão, mas que possui divergências internas. Desse modo, alguns trabalhadores usavam o GRUPO para debater especificamente e diretamente com outros colegas, fazendo suas críticas, réplicas e tréplicas que perduraram até um momento de ruptura: algumas trocas de ofensas entre eles geraram processo administrativo para averiguação e controle da situação e os gestores da LEGO decidiram desativar o GRUPO, já que ele era hospedado em seu ambiente virtual.
Entretanto, nessa história o GRUPO já não era somente uma lista de discussão: era uma prática de resistência combativa. Acrescento o adjetivo "combativa" na caracterização dessas práticas de resistência para dar ênfase na abordagem foucaultiana de poder. Para Foucault (2014), onde há relações de poder, há resistências mesmo que estas não transformem drasticamente essas relações. Para o autor, a disposição dos elementos, a tensão que uma resistência provoca na rede faz com que as relações de poder se alterem em busca de se manterem mais fortes. Percebese, assim, que em contraposição à estratégia de se desativar 0 GRUPO, alguns trabalhadores usaram como tática a criação de uma lista de discussão semelhante que fosse hospedada fora da LEGO, utilizando o "Yahoo!Grupos". 
Observa-se, também, alguns indícios do fortalecimento do poder disciplinar a partir dessa primeira coerção explícita em relação ao GRUPO, que visava conduzir os corpos a um tipo de comportamento no qual ofensas não eram aceitas, isto é, eram desvios. Foucault (2013b) sugere que a disciplina ao atuar no corpo por meio de coerções, estabelece um elo entre aptidão aumentada e dominação acentuada. Na LEGO, enquanto há um discurso oficial para fortalecimento da participação popular, os trabalhadores são disciplinados enquanto bons profissionais que devem renunciar a posturas políticas e comportamentos hostis para não comprometer a eficiência do processo de trabalho. Há de se fazer o questionamento: o trabalhador não é cidadão? Para a LEGO, aparentemente, não.

Apesar da LEGO ser um local no qual se fazem as leis, existe também o espaço normativo, das infrapenalidades. Muitos trabalhadores antigos se lembram de um ocorrido, entre 2001 e 2002, que marcou uma ruptura na história da LEGO e do GRUPO. Houve sugestões no GRUPO para que os trabalhadores protestassem contra ações da LEGO em um evento solene de posse de políticos usando narizes de palhaço. Entretanto, o que se ouve dessa história é que "cabeças rolaram". Mesmo que, a princípio, essa sanção pareça apenas repressiva, ela foi se desenvolvendo no corpo social de forma sutil, de modo a cumprir sua função normalizadora e produtiva, aliado ao olhar vigilante existente pelos participantes e não participantes do GRUPO.

Um aspecto observado desse percurso foi o fortalecimento do medo. Dessa forma, tanto para novatos quanto para antigos o medo é um tema recorrente. Até mesmo para a defesa de que "não se deve ter nada a temer". Advoga-se a estabilidade como argumento que garante aos trabalhadores a possibilidade de uma postura destemida. Não obstante, o medo continua ali, como um sentimento palpitante pronto a aflorar. Para contê-lo, basta a disciplinarização: saiba o que, quando, com quem, e como dizer, e saiba como agir, que não é preciso ter medo.

Foi possível observar como o castigo disciplinar estava ligado ao "ser profissional", que demanda cada vez mais tempo, mais atitudes adequadas diante do cargo e de suas atribuições, mais conformidade a uma regra, mais exercício do trabalho. Mesmo que "cabeças tenham rolado", seguindo a mesma metáfora, outras se impuseram no corpo, conseguindo cargos comissionados ou funções gratificadas.

Contudo, tais benefícios são um duplo: além de gratificação também podem ser considerados como castigos, uma vez que exigem um exercício intensificado para corrigir um desvio. Desvio este que era defender interesses individuais e coletivos, ser político, enfim, ser cidadão. Assim, como participar ou não do GRUPO pode classificar um indivíduo, o próprio GRUPO torna-se um sistema de classificação que vale como punição. Toda essa produção de individualidades ilustra a noção de poder positivo ou produtivo que referenciamos neste artigo.

Após o período de conflitos entre trabalhadores e gestores que permeou o final da década de 1990 e o início de 2000, houve um período de calmaria. Para Foucault (2010), as relações de poder são de múltiplas formas e o seu entrecruzamento delineia fatos gerais de dominação. Isso não significa que existe um grande estrategista por trás da estratégia que organiza a dominação, mas que há "procedimentos dispersados, heteromorfos e locais de poder [que] são reajustados, reforçados, transformados por essas estratégias globais, e tudo isso com numerosos fenômenos de inércia, de intervalos, de resistências" (Foucault, 2010, p. 249). Algo que parece movimentar novamente o jogo de poder, foi a configuração de exames que alteraram a disposição dos elementos na batalha: a LEGO fez dois grandes concursos para provimento de cargos efetivos, em 2001 e 2007.

Algumas características próprias desses concursos enquanto exames se referem à divisão que é feita entre trabalhadores do legislativo e dos outros poderes, havendo os mais difíceis, que se julgam selecionar os melhores profissionais com melhores salários, e os mais fáceis, na lógica inversa. Nesse sistema de classificação, os trabalhadores do legislativo seriam superiores aos do executivo, por exemplo, e são hierarquizados de acordo com a carreira e com as avaliações de desempenho, outros dois tipos de exame.

A chegada de novos trabalhadores também gera expectativas, positivas e negativas. Esperava-se que os novatos trouxessem mais profissionalização para o serviço público (esperança), mas também se receava uma mudança drástica no funcionamento das coisas na LEGO (ameaça).

No GRUPO, muitos participantes antigos esperavam uma postura mais destemida e combativa dos novatos. Acreditavam que tanto a questão da estabilidade, como uma forma de proteção a coerções que visassem interesses particulares, quanto os entendimentos sobre o que era ser servidor público (atuar em prol do interesse público de acordo com as regras impessoais da Administração Pública), favoreceriam o perfil esperado. Entretanto, o que se observou foi o fortalecimento do poder disciplinar (Foucault, 2013b) que mudou o diagrama de forças na LEGO, que pode ser percebido pela própria mudança no GRUPO em relação ao seu funcionamento, aos discursos publicados e aos seus efeitos enquanto prática social. 
Figura 8 - Mudança publicações do GRUPO

\author{
Mensagem 9 \\ De: jonas@lego.br \\ Para: servidor@lego.br \\ Assunto: 7 estratégias para se tornar indispensável na empresa em 2013 \\ http://economia.uol.com.br/ultimas-noticias/infomoney/2013/01/02/7-estrategias- \\ para-se-tornar-indispensavel-na-empresa-em-2013.jhtm
}

$02 / 01 / 2013$ - $08 \mathrm{~h} 54$

7 estratégias para se tornar indispensável na empresa em 2013

SÃO PAULO - O começo de um ano, para muitos, é um momento de mudanças e resoluções, com pensamentos positivos para o início uma nova etapa da vida. Nessa época, é inevitável também pensar em algo essencial: permanecer ou encontrar um emprego em 2013. Uma boa solução para realizar tal promessa é se tornar um profissional indispensável na sua empresa. Mas como? Veja sete estratégias formuladas pela Forbes que irão te ajudar nessa etapa:

1. Seja flexível - De acordo com uma pesquisa publicada no site, mais de $50 \%$ dos funcionários afirmam que foram flexíveis em seus empregos nos últimos 12 meses, com demandas de reorganizações de novos fluxos de trabalho. "Certifique-se de que seu chefe vê você como alguém preparado para trabalhar em outras áreas ou funções", disse o diretor de uma empresa de consultoria executiva, Brian Kropp.

2. Mantenha-se atualizado - "Se você não está regularmente por dentro das tendências e acontecimentos de seu ramo de atuação, você pode estar comprometendo seu crescimento profissional", analisa a vice-presidenta e co-diretora da Witt/Kieffer, Lucy Leske."'Manter-se atualizado sobre sua profissão sendo capaz de aplicar esses conhecimentos na prática. Isso demonstra a sua compreensão de sua posição na empresa e aonde quer chegar nela".

3. Não seja um solitário - Normalmente, $40 \%$ dos profissionais trabalham com mais de 20 pessoas e um só dia de trabalho e mais de $80 \%$ trabalham com dez. Saber se relacionar é mais do que um pré-requisito nas empresas, já é considerado normal. O funcionário que não tem essa habilidade precisa urgentemente mudar seus conceitos, sugerem os especialistas.

Fonte: dados da pesquisa

Ao observar a Figura 8, considerando o desenvolvimento e o fortalecimento do poder disciplinar na LEGO, percebe-se que as mensagens do GRUPO também passaram por um processo de normalização. As mensagens perdem o tom de revolta $e$ mobilização, adquirindo um tom informativo e de distanciamento do sujeito do texto. O GRUPO passa por uma fragmentação maior e também perde sua característica principal de resistência combativa. Consideramos que o GRUPO continua a ser uma prática de resistência, mas sua maleabilidade diante do jogo de poder a transformou numa prática de resistência normalizada, que segue alguns padrões dentro do contínuo do que é aceitável como normal para aquele GRUPO.

Ao fazer essa análise, acredita-se ser importante ressaltar que, como defende Foucault (2014), a história é descontínua, feita de acidentes e, na genealogia, não devemos buscar sentido oculto nas palavras, mas os sistemas de coação que as restringem, à norma que obedece cada série de enunciados, além das condições de aparecimento (Díaz, 2012).

Portanto, por mais que essa narrativa pareça linear e coerente, há de se considerar os procedimentos dispersos existentes nas disposições encontradas. Um deles seria o que denomino de resistência à resistência, isto é, uma prática de resistência dentro do próprio GRUPO.
As mensagens da Figura 9 fazem parte de um momento do GRUPO diferente daquele contextualizado do final da década de 1990, em que o GRUPO era resistência combativa. Aqui, em 2012, o produtor assume-se como parte de uma resistência, mas faz aconselhamentos aos que ainda não participam: "deixe claro para ele que é um caminho sem volta". Isto é, pode ser que ele queira voltar à normalidade e não consiga devido à estigmatização que existe aos resistentes. Observa-se, portanto, que a resistência já foi objetivada como o anormal, em um contínuo que designa como normal ter "chance de ocupar cargo de chefia". Para que haja esse sistema de classificação cuja própria existência já se configura como elemento de exclusão (bons = não resistentes, maus = resistentes), é necessário que haja poder disciplinar (vigilância, sanções normalizadoras e exames).

Destarte, todos os exames analisados na LEGO se valem do olhar vigilante e da sanção normalizadora para produzir o indivíduo, um trabalhador apolítico, especializado, profissional e competente que tem ambições quanto à uma carreira de sucesso. E essa instância de produção de saber está ancorada em relações de poder que erigem a defesa de tal profissional como uma força contra outra - a do funcionário público marajá - em um regime de verdade constituído pelos discursos da mídia, discursos científicos e discursos sociais, numa relação entre micro e macro poderes que se (des)enrolam na história. 
Figura 9 - Resistência à resistência

\author{
Mensagem 10 \\ De: vicente@lego.br \\ Para: servidor@lego.br \\ Assunto: Re: Questionário
}

A dissolução do poder em todas as esferas como mecanismo de transformar todos nós em servidores do povo, no sentido exato da palavra, também seria um forma de 'alinhar o pensamento' para o bem comum" [Carmen]:

Fala para o 'seu colega' que, se quiser participar da resistência, seja bem-vindo! Agora, deixe claro para ele que é um caminho sem volta: ele nunca terá chance de ocupar cargo de chefia. Nunca terá "e perfil de ser chefe", rs. Mas, para quem tem caráter, é melhor ocupar cargo de confiança do Povo, do que da confiança de um chefe que se afasta dos reais interesses públicos. [Vicente]

\title{
Mensagem 11 \\ De: julia@lego.br \\ Para: servidor@lego.br \\ Assunto: Re: Questionário
}

Entro na discussão pra comentar a resposta do [Vic ente]. Com ela dá pra sentir que não somos assim tão poucos. Os "(c) éticos", "sonhadores", "loucos", somos muito mais, já quase mudos porque esta lista, aparentemente democrática, reflete os mecanismos de dominação da Casa: o contraditório não é instrumento do diálogo, é rechaçado, é instrumento de estigmatização. Realmente é preciso rir do "nunca terá o perfil de chefe". É preferível a opção por ocupar um cargo de confiança do Povo. É uma opção mesmo, e podem crer, de uma $\begin{array}{llllll}\text { lucidez que } & \text { às } & \text { vem } & \text { demagogia. }\end{array}$

Qto ao resto: É preciso responder sim, não por acreditar que haverá uma mudança na gestão, afinal ela é baseada na "sobrevivência das espécies" ('vc é do meu grupo'). Hoje é um grupo, amanhã é outro, mas a filosofia é a mesma. E não será a implantação da "gestão de competências" que irá mudar, porque a filosofia do cumpadrio está enraizada e vem sendo repassada competentemente aos que estão chegando. (Confiram as mudanças de chefia, as tarefas concedidas, as representações, etc, porque vozes dissonantes aqui da lista, de repente se calaram). É preciso responder porque é mais um canal de desabafo (como esta lista aqui acaba sendo). É uma catarse para situações desconfortantes que presenciamos diariamente em nossos setores. Enfim porque é preciso ter ilusão, só assim vale a pena a luta Obs: Entreouvido após a palestra referida pela Cíntia: "fiquei constrangido pela pergunta que fizeram ao palestrante sobre a competência das chefias". É o vírus 'chefius serei' desseminando-se entre os novatos. Abs a todos

Fonte: Dados da pesquisa

Entretanto, há de ressaltar a heterogeneidade e a multiformidade das práticas sociais nas relações de poder. Os trechos "já quase mudos" e "vozes dissonantes aqui da lista, de repente se calaram" demonstram uma mudança em relação ao funcionamento e identificação do próprio GRUPO. Enquanto na década de 1990, havia resistência combativa, que articulava ações e manifestava insatisfações, nas mensagens de 2012, o GRUPO foi caracterizado pelo silêncio e rechaçamento do contraditório. Contudo, silêncio pode significar resistência, pois existe uma liberdade interior não conformista que modifica ou desvia a verdade imposta (Certeau, 1998).

Assim, ao que parece obediência e uniformização, é preciso identificar as diferenças, mesmo que se apresentem em nível micro. Certeau (1998) argumenta que elas sempre existirão na medida em que existirem relações desiguais de forças. Do mesmo modo que o silêncio pode ser compreendido como resistência em relação ao próprio GRUPO que outrora se configurava como prática de resistência combativa aos gestores, as mensagens da Figura 9 também parecem se tornar outra forma de resistência.

Mesmo que neste artigo esteja sendo evidenciado o fortalecimento e a transformação do poder disciplinar, não se pode deixar de supor que existem inúmeras artes de fazer/ resistir dos trabalhadores, como o simples fato de não participar do GRUPO ou de fazer publicações fora do que é esperado pelos participantes, como a publicação de poemas e músicas.

Nessa constante (re)configuração da rede, existe um movimento de transformação das relações de poder e resistências a partir do poder disciplinar, mas não há uma homogeneidade coerente. Ao mesmo tempo em que há resistências internas e externas ao GRUPO normalizado, há momentos pontuais em que os participantes desse grupo se unem como resistência combativa, como aconteceu na extinção do fundo de previdência dos trabalhadores em 2013, o que pode ser um tema para pesquisas futuras.

\section{Considerações finais}

Pensando nesses indivíduos e nos processos de subjetivação que os atravessam, questiono: "Quem é este trabalhador que participa do GRUPO e como se dão os processos de subjetivação vivenciados por ele?". Em nível macro, podemos entender que esse trabalhador foi atravessado por regimes de verdade que atrelam conceitos do Neoliberalismo e da Nova Gestão Pública a atividades 
e valores cotidianos na administração pública, como os conceitos de meritocracia, eficiência, especialização e menos ao de interesse público e bem comum.

Uma das formas de sustentação desses regimes é desenvolvimento de relações de poder com foco no poder disciplinar que buscam transformar indivíduos em corpos dóceis, por meio da vigilância, da sanção normalizadora e do exame. Contudo, ela não é exclusiva (existem outras formas de sustentação de regimes de verdade que não foram aqui estudadas), nem estanque (existe um jogo de forças em movimento). A análise dessas relações de forças (legitimação dos discursos dos "servidores marajás" e da "eficiência no serviço público", surgimento do sindicato, separação de instâncias política e administrativa, influência midiática, entre outras) levou à ênfase nos processos de subjetivação do sujeito, principalmente no efeito normalizador.

$\mathrm{Na}$ LEGO, a docilização dos corpos, com adestramento para atitudes que condizem com o que é ser um bom profissional, constitui o sujeito como resultado dessas relações de força, desses processos de subjetivação. Estes foram encontrados variando em um continuum normalizar...resistir...normalizar... Atreve-se aqui a dizer que possuem características de empreendimentos genealógicos: são heterogêneos, pois se diferem em ações, discursos, agentes etc.; multiformes, já que a forma de resistir pode ser diferente em cada contexto, como a resistência combativa, a resistência normalizada e outros tipos de resistências cotidianas que não foram abordadas nesta pesquisa, como o silêncio perante o GRUPO como forma de negá-lo; e descontínuos, porque não há continuidade nem ordem, são sempre fragmentados.

Os efeitos dessas relações produzem saberes e discursos, que sustentam o regime de verdade do Neoliberalismo e da Nova Gestão Pública, e constitui o próprio homem, trabalhador despolitizado da LEGO. Vale reiterar que por mais que haja neste artigo uma certa homogeneização do trabalhador da LEGO, há sempre possibilidades de resistências que movimentam as relações de poder, além de uma fragmentação existente entre os próprios trabalhadores. Portanto, a análise aqui exposta é situada e limitada.

Apesar das limitações, sugere-se como pesquisas futuras a realização de pesquisas genealógicas nos Estudos Organizacionais e a utilização de inovações metodológicas, como o uso de recursos virtuais enquanto fonte de dados, visto que ambas são escassas em nosso campo de conhecimento.

\section{Referências Bibliográficas}

Abumanssur, H. O.(2016). Breve ensaio sobre poder em Foucault. Revista Pensamento e Realidade, São Paulo, 31(4), 112-123.

Alcadipani, R., \& Almeida, A. (2000). Por Fora Bela Viola, Por Dentro... Análise Crítica Sobre A Gestão Do Espaço Nas Organizações Através De Um Estudo De Caso Sobre A Implementação De Um Escritório Aberto No Brasil. Organizações \& Sociedade, Salvador, V. 7(19), 35-52.

Anderson, P. (1995). Balanço Do Neoliberalismo. In: Sader, E., \& Gentili, P. (orgs.) Pós-Neoliberalismo: As Políticas Sociais E O Estado Democrático (pp. 9-23). Rio De Janeiro: Paz E Terra, 1995.

Barros, A. N., \& Carrieri, A. P. (2015). O Cotidiano E A História: Construindo Novos Olhares Na Administração. Revista De Administração De Empresas, São Paulo, 55(2), 151-161.

Bessi, V. G., Zimmer, M. V., \& Grisci, C. L. I.(2007). O Panóptico Digital Nas Organizações: Espaço-Temporalidade E Controle No Mundo Do Trabalho Contemporâneo. Organizações \& Sociedade, Salvador, 14(42), 83-96.

Bresser-Pereira, L. C.(1996). Da Administração Pública Burocrática À Gerencial. Revista Do Serviço Público, Brasília, 47(1), 7-40.
Brulon, V., Obayon, P., \& Rosenberg, G.(2012). A Reforma Gerencial Brasileira Em Questão: Contribuições Para Um Projeto Em Construção. Revista Do Serviço Público, Brasília, 63(3), 265-284.

Capobiango, R., do Nascimento, A., Silva, E., \& Faroni, W. (2013). Reformas Administrativas No Brasil: Uma Abordagem Teórica E Crítica Revista De Gestão, São Paulo, 20(1), 61-78

Cappelle, M. C. A., \& Brito, M. J.(2003). Poder Disciplinar E Gestão De Pessoas: Um Estudo Empírico Em Uma Organização De Desenvolvimento De Software. Organizações \& Sociedade, Salvador, 10(26), 19-37.

Castro, E. (2014). Introdução à Foucault (1 ${ }^{\mathrm{a}}$ edição). Belo Horizonte: Autêntica.

Cavalcanti, M. F. R., \& Alcadipani, R.(2011). Em Defesa De Uma Crítica Organizacional Pós-Estruturalista: Recuperando O Pragmatismo Foucaultiano-Deleuziano. Administração: Ensino E Pesquisa, Rio De Janeiro, 12(4), 557-582.

Certeau, M.(1998). A Invenção Do Cotidiano: Artes De Fazer (3ª edição) Petrópolis: Vozes.

Clegg, S. (1994). Weber and Foucault: Social Theory for the Study of Organizations. Organization, London, 1(1),149-178.

Costa, F. Z. N., Guerra, J.R. F. \& Leão, A. L. M. S.(2013). O Solo Epistemológico De Michel Foucault: Possibilidades De Pesquisa No Campo Da Administração. Revista De Ciências Da Administração, 15(35), 168-179.

Costa, A. S. M., Barros, D. F., \& Martins, P. E. M.(2010). Perspectiva Histórica Em Administração: Novos Objetos, Novos Problemas, Novas Abordagens. Revista De Administração De Empresas, São Paulo, 50(3), 288-299.

Díaz, E.(2012). A Filosofia De Michel Foucault (1ª edição). São Paulo: Unesp. Dreyfus, H. L., \& Rabinow, P.(2013). Michel Foucault: Uma Trajetória Filosófica: Para Além Do Estruturalismo E Da Hermenêutica (2ª ed. rev.). Rio De Janeiro: Forense Universitária.

Fairclough, N.(2001). Discurso e mudança social. Brasília: UnB

Fairclough, N.(2003). Analysing discourse: textual analysis for socia research. London: Routledge.

Ferreirinha, I. M. N., \& Raitz, T. R.(2010). As Relações De Poder Em Michel Foucault: Reflexões Teóricas. Revista De Administração Pública, Rio De Janeiro, 44(2), 367-83.

Fontoura, Y., Alfaia, L., \& Fernandes, A. (2013). A pesquisa histórica em estudos organizacionais no Brasil: uma análise paradigmática e novas perspectivas. GESTÃO.Org - Revista Eletrônica de Gestão Organizacional 11(1), 83-103.

Foucault, Michel.(2010). Estratégia, Poder-Saber ( $2^{\underline{a}}$ edição). Rio De Janeiro: Forense Universitária

Foucault, Michel.(2013a). A Ordem Do Discurso (23ª edição). São Paulo: Loyola.

Foucault, Michel.(2013b). Vigiar E Punir: Nascimento Da Prisão (41ª edição). Petrópolis: Vozes.

Foucault, Michel.(2014). Microfísica Do Poder (28ª edição). Rio De Janeiro: Paz E Terra.

Fuks, M.(2010). Más Notícias: A Cobertura Do Jornal [] E A Imagem Pública Da [LEGO] (1999-2003). Revista Sociologia Política, Curitiba, 18(36), 257 276.

Godoy, A. S. (2006). Estudo de caso qualitativo. In: Godoi, C. K., BandeiraDe-Mello, R., \& Silva, B. S. Pesquisa qualitativa em estudos organizacionais paradigmas, estratégias e métodos (pp. 115-146). São Paulo: Saraiva.

Ibarra, D.(2011). O Neoliberalismo Na América Latina. Revista De Economia Política, 31(2), 238-248.

Lana, R. D., Paines, P. A., Bonaldo, S. A., \& Muller, F. M. (2016). As Organizações como Fonte de Conflitos de Poder . Revista de Administração da UFSM, 9(3), 506-519.

Lemos, A. H. C., Rodriguez, D. A., \& Monteiro, V. C.(2011). Empregabilidade E Sociedade Disciplinar: Uma Análise Do Discurso Do Trabalho Contemporâneo À Luz De Categorias Foucaultianas. Organizações \& Sociedade, Salvador, 18(59), 587-604.

Lima J., Olavo B. (1998). As Reformas Administrativas No Brasil: Modelos Sucessos E Fracassos. Revista Do Serviço Público, 49(2), 5-32.

Mintzberg, H. (1992). El poder en la organización. Barcelona: Editorial Arie S.A.

Mintzberg, H. (1995). Criando organizações eficazes: estruturas em cinco configurações. São Paulo: Atlas.

Misoczky, M. C., Flores, R. K., \& Bohm, S.(2008). A Práxis Da Resistência E A Hegemonia Da Organização. Organizações \& Sociedade, Salvador, 15(45), 181-193.

Misoczky, M. C., M., Joysi, \& Flores, R. K.(2009). Gramsci E Paulo Freire Referências Fundamentais Para Os Atos Da Denúncia E Do Anúncio. Cadernos Ebape.Br, Rio De Janeiro, 7(3), 448-471.

Paes De Paula, A. P.(2005a). Administração Pública Brasileira Entre O Gerencialismo E A Gestão Social. Revista de Administração de Empresas, São Paulo, 45(1), 36-49.

Paes De Paula, A. P.(2005b). Por Uma Nova Gestão Pública: Limites E Potencialidades Da Experiência Contemporânea. Rio De Janeiro: FGV. 
Pereira, R. D.(2014). Sobre Heróis, Coronéis E Operários:Notas Acerca Da Disciplina Do Corpo E Da Ortopedia Da Alma Em Uma Companhia Têxtil De Minas Gerais. Tese de doutoramento não publicada, Centro De Pesquisa E Pós-Graduação Em Administração, Universidade Federal De Minas Gerais, Belo Horizonte, Brasil.

Pereira, Rafael D., Oliveira, Janete L., \& Carrieri, Alexandre P.(2012). O Poder, A Analítica Foucaultiana E Possíveis (des)caminhos: Uma Reflexão Sobre As Relações De Poder Em Organizações Familiares. Revista Eletrônica De Gestão Organizacional, Recife, 10(3), 623-652.

Pereira, W. E. N.(2004). Do Estado Liberal Ao Neoliberal. Interface, Natal, 1(1), 9-25.

Revista Veja (1988). A Guerra ao turbante. São Paulo, SP: Autor.

Santos, G. A. F., \& Claro, J. A. C. D. S. (2014). Poder e Política nas Organizações, à Luz das Teorias Organizacionais: um estudo bibliométrico nos anais do EnAnpad. Revista Eletrônica Gestão e Serviços, 5(1), 812-826.

Secchi, L.(2009). Modelos Organizacionais E Reformas Da Administração Pública. Revista De Administração Pública, Rio De Janeiro, 43(2), 347-69.

Serva, M.(1992). A Importação De Metodologias Administrativas No Brasil Uma Análise Semiológica. Revista De Administração Pública, Rio De Janeiro, 26(4), 128-44.

Silva, R. C., \& Alcadipani, R.(2004). As Transformações Do Controle Na Siderúrgica Riograndense: Uma Análise Foucaultiana. Organizações \& Sociedade, Salvador, 11(29), 81-96.

Souza, E. M., \& Costa, A. M.(2013). Usos E Significados Do Conhecimento Histórico Em Estudos Organizacionais: Uma (re)leitura Do Taylorismo Sob A
Perspectiva Do Poder Disciplinar. Cadernos Ebape.Br, Rio De Janeiro, 11(1), $1-15$.

Souza, E. M., Junquilho, G. S., Machado, L. D., \& Bianco, M. F. (2006). A Analítica De Foucault E Suas Implicações Nos Estudos Organizacionais Sobre Poder. Organizações \& Sociedade, Salvador, 13(36),13-25.

Souza, E. M., Machado, L. D., \& Bianco, M. F. (2008). O Homem E O PósEstruturalismo Foucaultiano: Implicações Nos Estudos Organizacionais. Organizações \& Sociedade, Salvador, 15(47), 71-86.

Stake, R. E. (1994). Case studies. In: Dezin, N. K., \& Lincoln, Y. S. (Eds.). Handbook of qualitative research (pp. 236-247). London: Sage.

Stassun, C. C. S. \& Prado Filho, K.(2012). Geoprocessamento Como Prática Biopolítica No Governo Municipal. Revista De Administração Pública, Rio De Janeiro, 46(6), 1649-1669.

Veneu, M. G.(1990). Representações Do Funcionário Público. Revista De Administração Pública, Rio De Janeiro, 24(1), 5-16.

Vizeu, F. (2010). Potencialidades Da Análise Histórica Nos Estudos Organizacionais Brasileiros. Revista De Administração De Empresas, São Paulo, 50(1), 37-47.

Xavier, W. G., \& Godoi, C. K.(2010) Panopticon Acadêmico. Revista Gestão \& Planejamento, 11(1), 91-103.

Zaccarelli, L. M., \& Godoy, A, S. (2013). "Deixa eu te contar uma coisa..." possibilidades do uso de narrativas e sua análise nas pesquisas em organizações. Revista Gestão Organizacional, 6(3), 25-36. 